VOLUME 15 N0. 1

JUNE 2018

ISSN 1675-7009

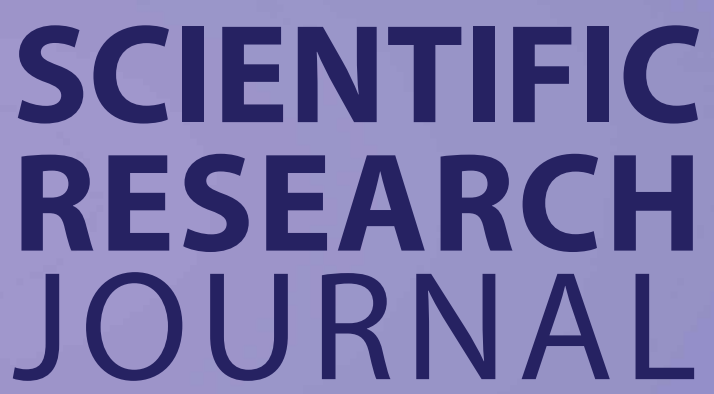

\title{
Institute of Research Management and Innovation
}

Seismic Response of a Base Isolated Cable-Stayed Bridge Under Near-Fault Ground Motion Excitations

Ahad Javanmardi, Zainah Ibrahim, Khaled Ghaedi, Mohammed Jamee, Usman Hanif \& Meisam Gordan

Bending Strength of Steel Fibre Reinforced Concrete Ribbed Slab Panel

Amir Syafiq Samsudin, Mohd Hisbany Mohd Hashim, Siti Hawa Hamzah \& Afidah Abu Bakar

Preliminary Investigation on the Flexural Behaviour of Steel Fibre Reinforced Self-Compacting Concrete Ribbed Slab

Nur Aiman Suparlan, Muhammad Azrul Ku Ayob, Hazrina Ahmad, Siti Hawa Hamzah \& Mohd Hisbany Mohd Hashim

Strength Performance of Sustainable Mortar Containing Recycle Sewage Sludge Ash (SSA) Nurul Nazierah Mohd Yusri, Kartini Kamaruddin, Hamidah Mohd Saman \& Nuraini Tutur

Pull-Out Performance of T-Stub End Plate Connected to Concrete Filled Thin-Walled Steel Tube (CFTST) using Lindapter Hollo-Bolts Nazrul Azmi Ahmad Zamri, Clotilda Petrus, Azmi lbrahim \& Hanizah Ab Hamid

The Application of Waste Marble as Coarse Aggregate in Concrete Production Kolk rung Ghang, Wail Hoe Kwan \& Hui Bun Kua 


\title{
SCIENTIFIC RESEARCH JOURNAL
}

\section{Chief Editor}

Hamidah Mohd Saman

Universiti Teknologi MARA, Malaysia

\section{Managing Editor}

Yazmin Sahol Hamid

Universiti Teknologi MARA, Malaysia

\section{International Editors}

R. Rajakuperan, B.S.Abdur Rahman University, India Vasudeo Zambare, South Dakota School of Mines and Technology, USA Greg Tan, University of Notre Dame, Australia

Pauline Rudd, National Institute for Bioprocessing Research \& Training, Dublin, Ireland Wanida Jinsart, Chulalongkorn University, Thailand Chantra Tongcumpou, Chulalongkorn University, Thailand

Panwadee Suwattiga, King Mongkuts University of Technology North Bangkok, Thailand

\section{Editorial Board}

\author{
Nor Ashikin Mohamed Noor Khan, Universiti Teknologi MARA, Malaysia \\ Yahaya Ahmad, University of Malaya, Malaysia \\ Faredia Ahmad, Universiti Teknologi Malaysia, Malaysia \\ Abdul Rahman Mohd. Sam, Universiti Teknologi Malaysia, Malaysia \\ Mohd Nizam Ab Rahman, Universiti Kebangsaan Malaysia, Malaysia \\ Ismail Musirin, Universiti Teknologi MARA, Malaysia \\ Nooritawati Md Tahir, Universiti Teknologi MARA, Malaysia \\ Ahmad Taufek Abdul Rahman, Universiti Teknologi MARA, Malaysia \\ Zulkiflee Latif, Universiti Teknologi MARA, Malaysia
}

\section{Journal Administrators}

Khairul Nurudin Ahnaf Khaini, Universiti Teknologi MARA, Malaysia Nurul Iza Umat, Universiti Teknologi MARA, Malaysia

\section{(C) UiTM Press, UiTM 2018}

All rights reserved. No part of this publication may be reproduced, copied, stored in any retrieval system or transmitted in any form or by any means; electronic, mechanical, photocopying, recording or otherwise; withoutprior permission in writing from the Director of UiTM Press, Universiti Teknologi MARA, 40450 Shah Alam, Selangor Darul Ehsan, Malaysia.E-mail: penerbit@salam.uitm.edu.my

Scientific Research Journal is a journal by Institute of Research Management \& Innovation (IRMI), Universiti Teknologi MARA, Bangunan Wawasan, Level 3, 40450 Shah Alam, Selangor Darul Ehsan, Malaysia.E-mail: irmiuitm@salam.uitm.edu.my

The views, opinions and technical recommendations expressed by the contributors and authors are entirely their own and do not necessarily reflect the views of the editors, the publisher and the university. 


\section{SCIENTIFIC \\ RESEARCH \\ JOURNAL}

Institute of Research Management \& Innovation (IRMI)

\begin{tabular}{lll}
\hline Vol. 15 No. 1 & June 2018 & ISSN 1675-7009 \\
\hline
\end{tabular}

1. Seismic Response of a Base Isolated Cable-Stayed Bridge Under Near-Fault Ground Motion Excitations Ahad Javanmardi

Zainab Ibrahim

Khaled Gheadi

Mohammed Jameel

Usman Hanif

Meisam Gordan

2. Bending Strength of Steel Fibre Reinforced Concrete Ribbed Slab Panel

Amir Syafiq Samsudin

Mohd Hisbany Mohd Hashim

Siti Hawa Hamzah

Afidah Abu Bakar

3. Preliminary Investigation on the Flexural Behaviour

of Steel Fibre Reinforced Self-Compacting Concrete Ribbed Slab

Nur Aiman Suparlan

Muhammad Azrul Ku Ayob

Hazrina Ahmad

Siti Hawa Hamzah

Mohd Hisbany Mohd Hashim 
4. Strength Performance of Sustainable Mortar

Containing Recycle Sewage Sludge Ash (SSA)

Nurul Nazierah Mohd Yusri

Kartini Kamaruddin

Hamidah Mohd Saman

Nuraini Tutur

5. Pull-Out Performance of T-Stub End Plate Connected To Concrete Filled Thin-Walled Steel Tube (CFTST)

Using Lindapter Hollo-Bolts

Nazrul Azmi Ahmad Zamri

Clotilda Petrus

Azmi Ibrahim

Hanizah Ab Hamid

6. The Application of Waste Marble as Coarse Aggregate in Concrete Production

Kok Yung Chang

Wai Hoe Kwan

Hui Bun Kua 


\title{
Pull-Out Performance of T-Stub End Plate Connected To Concrete Filled Thin-Walled Steel Tube (CFTST) using Lindapter Hollo-Bolts
}

Nazrul Azmi Ahmad Zamri ${ }^{1}$, Clotilda Petrus, Azmi Ibrahim, Hanizah Ab Hamid

\author{
Faculty of Civil Engineering, Universiti Teknologi MARA (UiTM), \\ 40450 Shah Alam, Selangor Darul Ehsan, Malaysia \\ 'E-mail:nazrul_azmi@yahoo.com
}

Received: 1 March 2018

Accepted: 1 April 2018

\section{ABSTRACT}

The application of concrete filled steel tubes (CFSTs) as composite members has widely been used around the world and is becoming popular day by day for structural application especially in earthquake regions. This paper indicates that an experimental study was conducted to comprehend the behaviour of T-stub end plates connected to concrete filled thin-walled steel tube (CFTST) with different types of bolts and are subjected to pullout load. The bolts used are normal type bolt M20 grade 8.8 and Lindapter Hollo-bolt HB16 and HB20. A series of $10 \mathrm{~mm}$ thick T-stub end plates were fastened to $2 \mathrm{~mm}$ CFTST of $200 \mathrm{~mm} \times 200 \mathrm{~mm}$ in cross-section. All of the specimens were subjected to monotonic pull-out load until failure. Based on test results, the Lidapter Hollo-bolts showed better performance compare to normal bolts. The highest ultimate limit load for T-stub end plate fasten with Lindapter Hollo-bolt is four times higher than with normal bolt although all end plates show similar behaviour and failure mode patterns. It can be concluded that T-stub end plate with Lindapter Hollo-bolt shows a better performance in the service limit and ultimate limit states according to the regulations in the design codes.

Keywords: CFTST, Steel beam, T-stub end plate, connection, Hollo-bolt 


\section{INTRODUCTION}

To date, the Construction Industry Development Board (CIDB) is intensively encouraging Malaysian construction industries to develop an advance method for the capacity and capability in construction industries by introducing the implementation of Industrialised Building System (IBS). IBS is a construction system in which some parts are manufactured in factories, then are positioned and assembled into a structure on or off site with little extra site works [1]. Concrete filled steel tube (CFST) is a composite structural member where the steel hollow tube is made in factory, assembled and then filled up with concrete at construction site.

The steel hollow tube is used as permanent formwork as well as reinforcement for the structure and the concrete filled inside the hollow section increase the load capacities. It prevents the steel hollow tube to inward buckling. A CFST column is a structural system with excellent characteristics structurally, economically as compared to other types of columns such as the traditional reinforced concrete columns and steel columns.

A CFST offers many structural benefits such as has high compressive strength and ductility, has excellent earthquake resistance, is able to reduce cost and duration for the construction. These advantages have been widely exploited and have led to the extensive use of CFSTs in civil engineering structures. Many developed countries and also earthquake prone countries such as the United States, China, Australia have done many researches and using the system in their structural practices.

The utilisation of thin walled steel tube filled with concrete allows an economical solution primarily for an axially loaded column. For economical purposes, a thin walled steel section is sufficient to carry the construction loading while relatively inexpensive concrete is used as the major component to carry the design loading [2]. Studies done by [3-5] on the structural behaviour of concrete filled thin-walled steel tubes (CFTST) have proven that the performance of the thin-walled steel columns can be improved by providing sufficient internal stiffeners. However in these studies, the structural behaviour of CFTST columns were done in isolation. In order to apply CFTST columns in construction, a feasible connection between the column and beam must be identified. 


\section{STEEL BEAM-COLUMN CONNECTIONS}

The use of concrete-filled steel tube (CFST) columns has become increasingly popular for civil engineering structures in developed countries such as England, Japan, United States of America for high rise buildings, bridges and other structural applications due to excellent earthquake resistance, ductility and also high strength capacity [6-7]. Due to this fact, many researchers have came out with various research works in order to enhance the beam to CFST column connections such as combination of welding and cutting through the steel hollow tubes [8]. These also included study on the effect of the different types of blind bolts [9], the effect of stiffness, strength of the connection using different end plate types and thicknesses [10].

Researchers [8][11] conducted studies on different types of beamcolumn connections such as simple welded connection, diaphragm connection, extending the steel beam through the steel tube, added weldable bars on top and bottom of the simple welded connection. Some of the connections showed very outstanding performances in the moment resisting and inelastic cyclic behaviour while the others were not. The most outstanding is the steel beam extended through the steel tube. This connection exhibits stable strain-hardening behaviour, develops a full plastic hinge in the beam-column connection and it can be used in regions of high seismic risk. However, the use of these types of connections has not always been convenient in construction practice. Considerable work during erection is required, in addition to extensive welding and high tolerances required in detailing.

In 2012, Wang and Guo [10] conducted a study on the connections of steel beams and concrete filled thin-walled steel tubes. Their study focusedon the effect of connections of flush and extended end plates onto two (2) different thicknesses of the steel hollow tubes namely $1.5 \mathrm{~mm}$ and $3 \mathrm{~mm}$ using extended blind bolts. It was found that the extended end plate showed better result compare to the flush end plate. Other than that, the thicker steel tube has lower deformation and higher moment capacity compare to the thinner steel tubes. Moreover, there was no sign of bending or shear deformation of the bolts in the tests except for the concrete near the bolts in tension which showed crack. 
In 2011, a group of researchers from the Steel Construction Institute (SCI) and the British Constructional Steelwork Association (BCSA) has published guidance that covers a range of steelwork connections. The guidance focuses on nominally pinned joints that primarily carry vertical shear and, as an accidental limit state, tying forces, designed in accordance with Eurocode 3 and it's UK National Annexes [12]. Figure 1 shows the main components of steel connections as given in the guidance publication. However, this guidance is mainly for open section (H-section or C-section) and hollow section column without any infilled concrete.

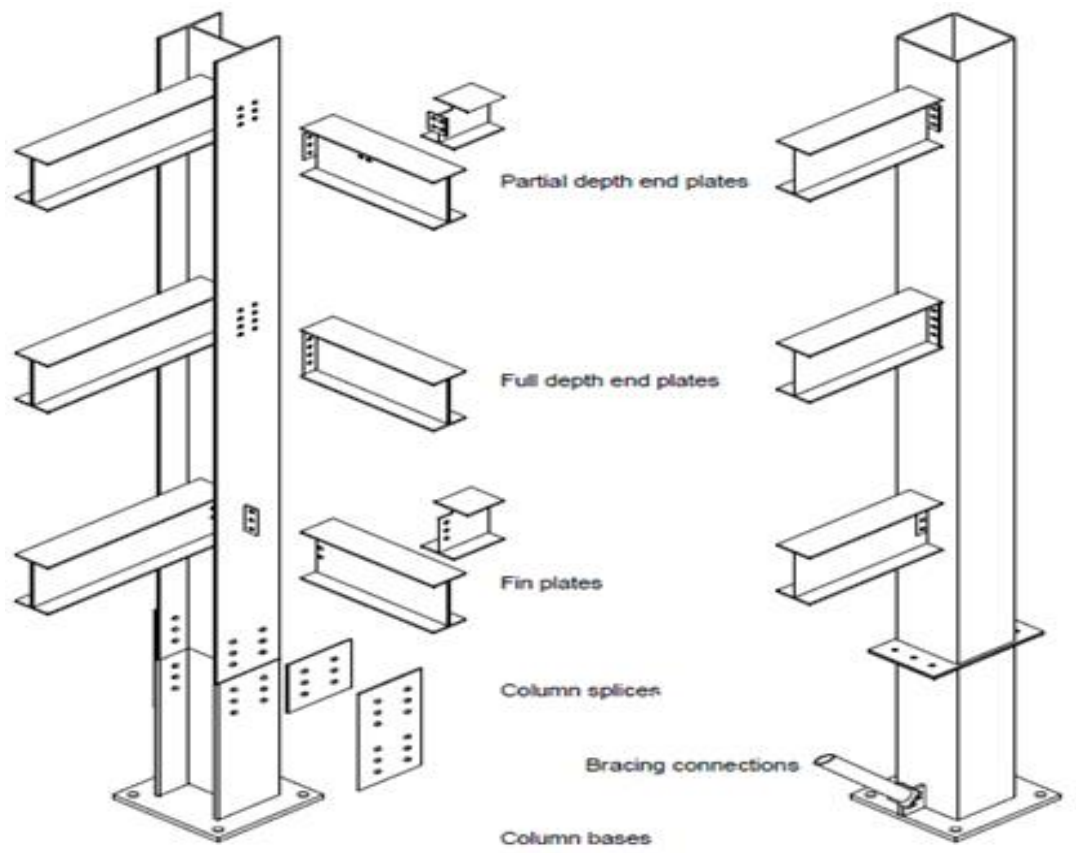

Figure 1: Typical Connections of Steel Column using Bolts [12]

From previous researches, it can be concluded that the usage of end plates shows a promising performance, however, the moment resistance of this connection is still lower compare to the beam through the steel tube connection. Moreover, the design guidance provided is still lacking especially for thin-walled section and also filled section. Thus, in order to fill this gap, a series of investigation has been carried out on T-stub end plate connected to concrete filled thin-walled steel tube (CFTST) with different types of bolts. 


\section{EXPERIMENTAL WORK}

For this study, a laboratory work had been done where the T-stub end plate connecting to the skin of CFTST with two different types of bolts. A total of six specimens were prepared and tested. Two specimens were using normal bolts, whereas the other four were using Lindapter Hollo-bolts. Table 1 shows the summarised parameters for each specimen for this study. The size of square hollow section (SHS) for the CFST is $200 \mathrm{~mm} \times 200 \mathrm{~mm}$, the thickness is $2 \mathrm{~mm}$ and total length is $1200 \mathrm{~mm}$. The SHS was fabricated from four (4) pieces of cold formed lipped angles that were seam weld to form a SHS with longitudinal stiffeners. The height of each longitudinal stiffener is $25 \mathrm{~mm}$. Figure 2 shows how the sequence of SHS was fabricated.

Table 1: Parameters of Bolts for All Specimens

\begin{tabular}{|l|l|c|c|c|}
\hline Specimen & Type of Bolt & $\begin{array}{l}\text { Bolt Size } \\
(\mathbf{m m})\end{array}$ & $\begin{array}{l}\text { Bolt Lenght } \\
(\mathbf{m m})\end{array}$ & Bolt Grade \\
\hline B20-1 & Normal bolt & 20 & 90 & 8.8 \\
\hline B20-2 & Normal bolt & 20 & 120 & 8.8 \\
\hline HB20-1 & Hollo-bolt & 20 & 90 & 8.8 \\
\hline HB20-2 & Hollo-bolt & 20 & 120 & 8.8 \\
\hline HB16-1 & Hollo-bolt & 16 & 75 & 8.8 \\
\hline HB16-2 & Hollo-bolt & 16 & 100 & 8.8 \\
\hline
\end{tabular}

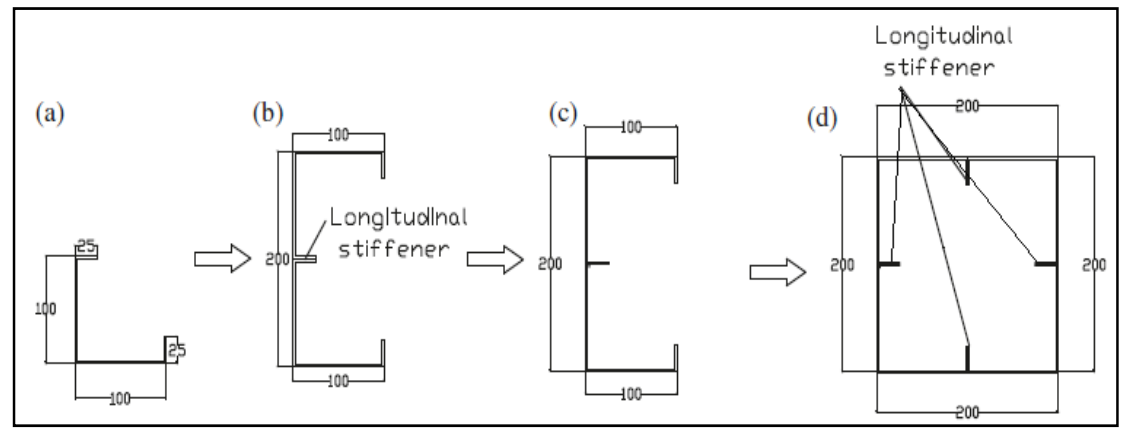

Figure 2: The Formation of the Steel Hollow Tube with Stiffeners (source by author) 
M20 grade 8.8 normal bolts, HB16 and HB20 Lindapter Hollo-bolts were used to connect the T-stub to the CFTST skin. Additional parameter which is the different length of the each bolt had also been observed. Figure 3 and 4 show the dimensions and components of the Lindapter Hollo-bolt respectively.
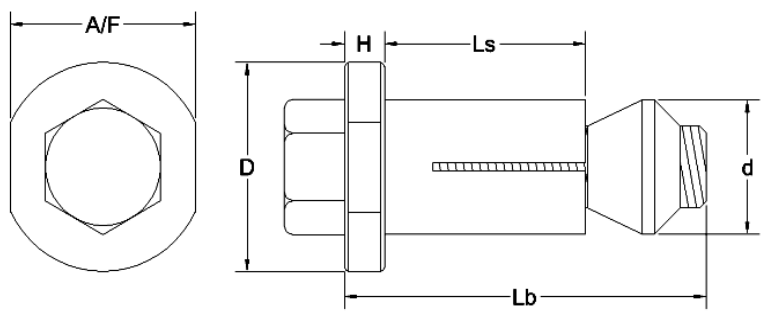

\begin{tabular}{|c|c|c|c|c|c|c|c|}
\hline Bolt type & $\begin{array}{c}\text { Bolt } \\
\text { diameter, } \\
\mathrm{d}_{\mathrm{b}}(\mathrm{mm})\end{array}$ & $\begin{array}{c}\text { Bolt } \\
\text { length, } \\
\mathrm{L}_{\mathrm{b}} \\
(\mathrm{mm})\end{array}$ & $\begin{array}{c}\text { Sleeve } \\
\text { length, } \\
\mathrm{L}_{\mathrm{s}} \\
(\mathrm{mm})\end{array}$ & $\begin{array}{c}\text { Sleeve } \\
\text { diameter, } \\
\mathrm{d}(\mathrm{mm})\end{array}$ & $\begin{array}{c}\text { Collar } \\
\text { Thickness, } \\
\mathrm{H}(\mathrm{mm})\end{array}$ & $\begin{array}{c}\text { Collar } \\
\text { Thickness, } \\
\mathrm{D}(\mathrm{mm})\end{array}$ & $\begin{array}{c}\text { Collar } \\
\text { Across } \\
\text { flat, } \\
\mathrm{A} / \mathrm{F} \\
(\mathrm{mm})\end{array}$ \\
\hline HB16-1 & 16 & 75 & 41.5 & 25.75 & 8 & 38 & 36 \\
\hline HB16-2 & 16 & 100 & 41.5 & 25.75 & 8 & 38 & 36 \\
\hline HB20-1 & 20 & 90 & 50 & 32.75 & 10 & 51 & 46 \\
\hline HB20-2 & 20 & 120 & 50 & 32.75 & 10 & 51 & 46 \\
\hline
\end{tabular}

Figure 3: Dimensions of Hollo-Bolt Components (source by author)
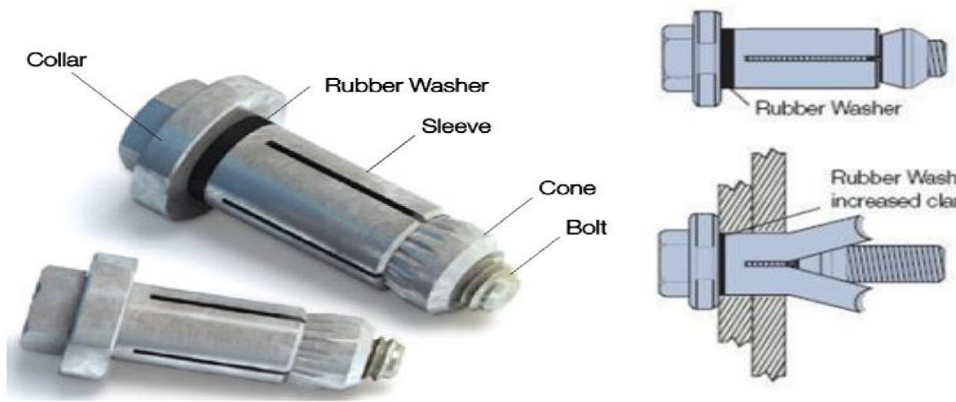

Figure 4: Components of Lindapter Hollo-Bolt [13] 
The dimensions of the T-stub end plate and steel hollow section are consistent for all specimens. The dimensions of steel sections and bolt locations are shown in Figure 5.
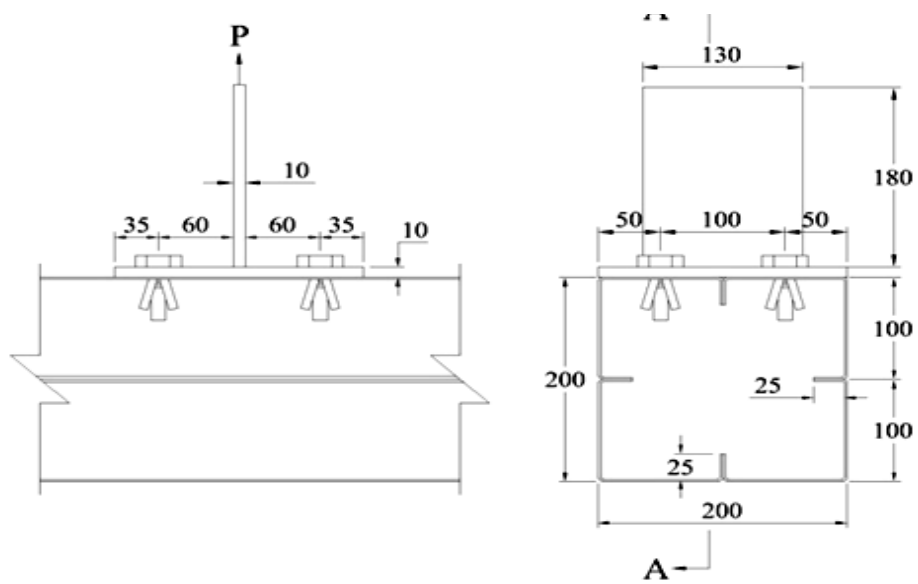

Figure 5: The Arrangement of Hollo-Bolt and T-Stub End Plate (All Dimensions are in $\mathrm{mm}$ ) (source by author)

The installation for the T-stub end plate is different for the normal bolts compare to Lindapter Hollo-bolts. To fasten normal bolts, both sides of the bolts which are inside and outside of the steel hollow section need to be reachable and secure. It is proven that this method is not very suitable for onsite practices. Different to normal bolts, Lindapter Hollo-bolts can be fasten from outside of the hollow section only. Figure 6 shows installation steps for Hollo-bolts.

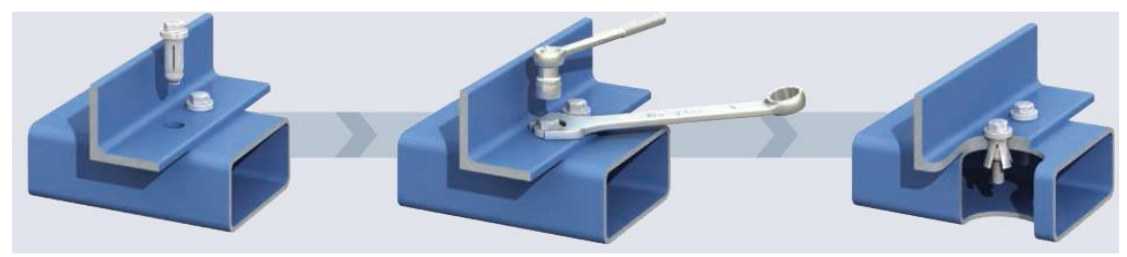

Figure 6: Installation of Hollo-Bolt [13] 


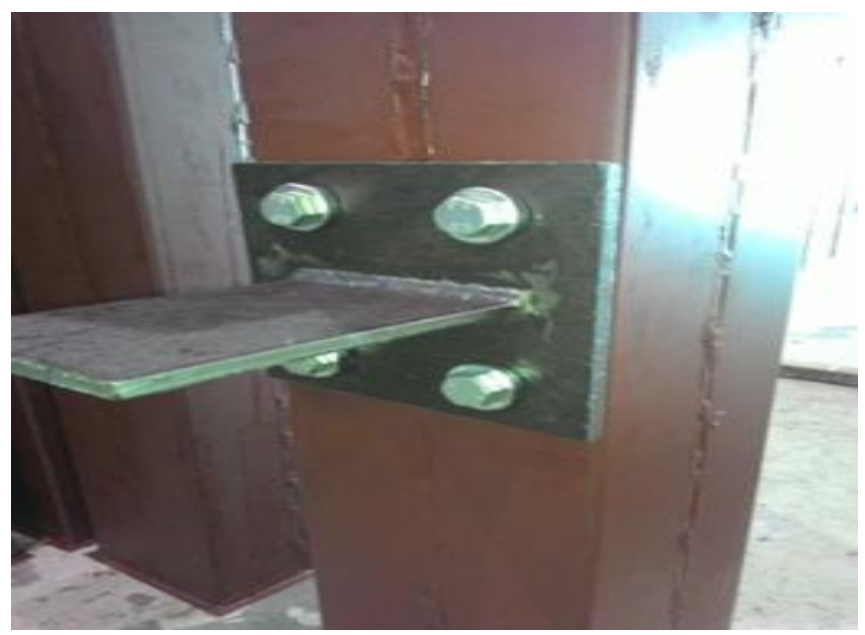

Figure 7: Completed Assemblage of T-Stub End Plate to the CFST using Hollo-Bolt (source by author)

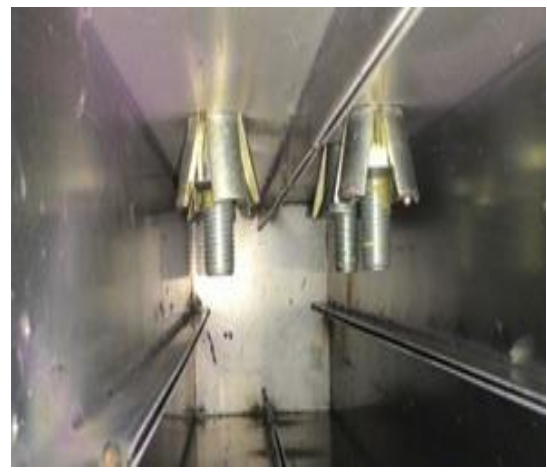

(a)

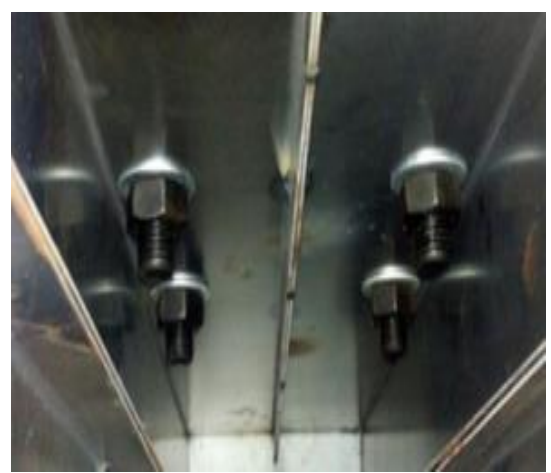

(b)

Figure 8: Different Setting of (a) Hollo-Bolt and (b) Normal Bolt After Installation (source by author)

Figure 7 show the assemblage of T-stub end plate to the CFST column with Hollo-bolts, while Figure 8 shows differences between normal bolts and Hollo-bolts installation setting inside the steel hollow tubes. Compare to normal bolts, the Hollo-bolts sleeve can improve the bonding between the bolts and concrete. Figure 9 and Figure 10 show the support setup of CFST and T-stub end plate respectively for the pull-out test. The specimens were tested until failure under monotonic load. All data and behaviour of the specimens were recorded and observed. 
VOL . 15 No. 1, JUNE 2018

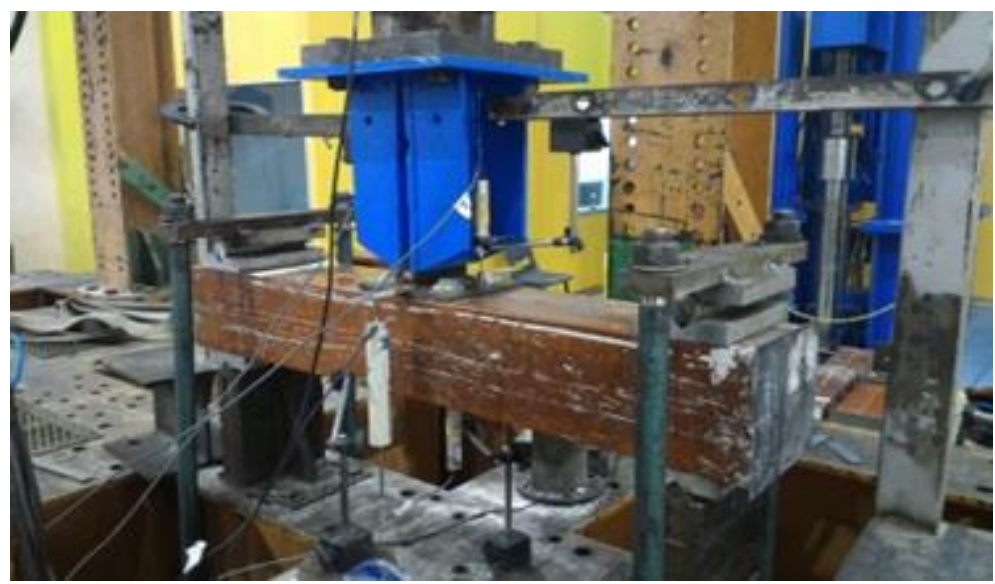

Figure 9: Overall Setup for the Pull-Out Experiment (source by author)

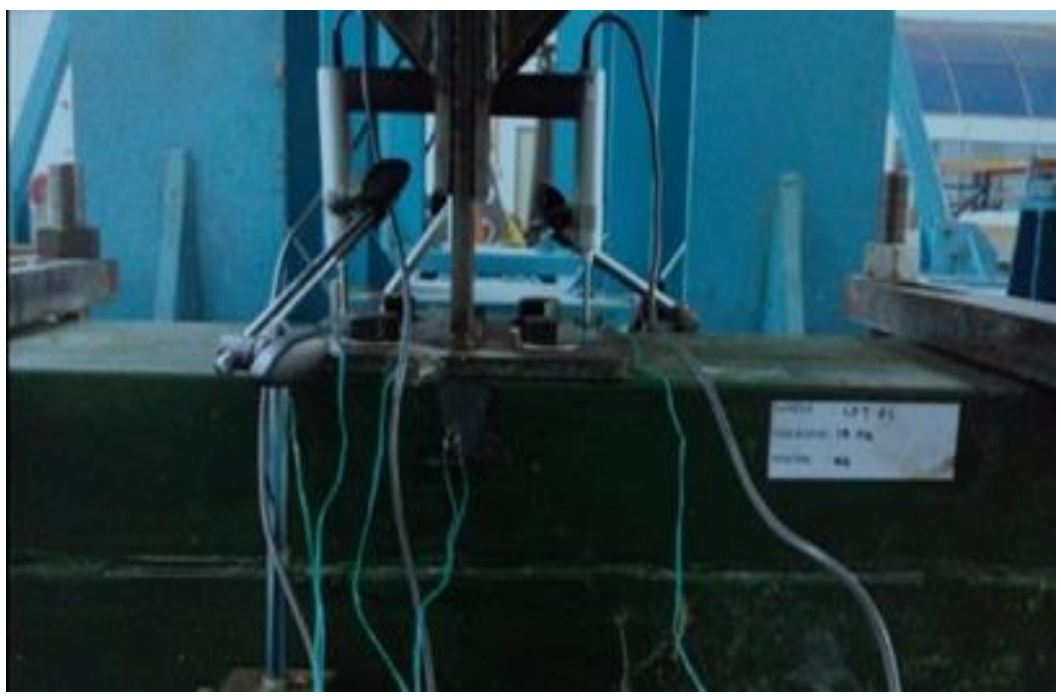

Figure 10: The T-Stump End Plate Setting for the Test (source by author) 


\section{RESULTS AND DISCUSSION}

The concrete used for this experiment was designed for grade $\mathrm{C} 30$ and the tensile strength for the steel sections are $403 \mathrm{MPa}$ and $330 \mathrm{MPa}$ for $2 \mathrm{~mm}$ and $10 \mathrm{~mm}$ steel plate respectively. The concrete strength for each specimen was different because each concrete batch has to be mixed at different times due to lack of concrete mixer capacity for each mix. Therefore, the results shown had been normalised according to the concrete strength for each specimen.

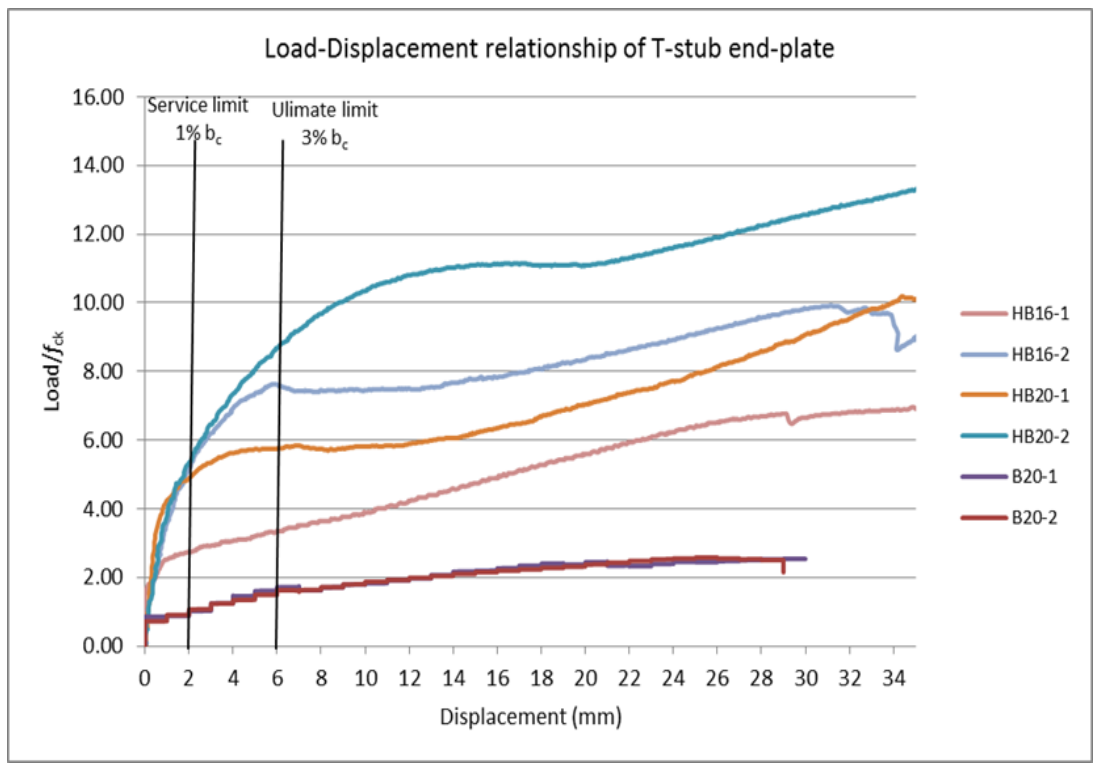

Figure 11: The Load-Displacement Behaviour of the Specimens (source by author)

The load-displacement relationship curves of the specimens were plotted and are shown in Figure 10. Each load was plotted against a transducer at mid-point of the end plate where the displacement at this point is most critical. From the graph, the specimens with normal bolts do not contribute much even though different lengths of the bolts were used. The specimens with Hollo-bolts showed better performance where they resisted higher loads compare to the normal bolts. 
International Institute of Welding, IIW [14] and [15] recommended that the T-stub should be designed to transfer a limited amount of tension force in order to ensure that the column face deformation will not exceed serviceability limit state at $1 \%$ of the column width and will be no more than ultimate limit state at $3 \%$ of the column width where in this study serviceability and ultimate limit state are at $2 \mathrm{~mm}$ and $6 \mathrm{~mm}$, respectively.

The graphs in Figure 11 indicate that T-stub end plates connected with normal bolts have the lowest value of load for both service and ultimate limit states. By using Hollo-bolts, there is huge increase in loads for both limit states. Even though the load factor for ultimate limit state for HB162, HB20-1 and HB20-2 are different, the load values for service limit state are almost the same at $5.0 \mathrm{kN} / \mathrm{fck}$.

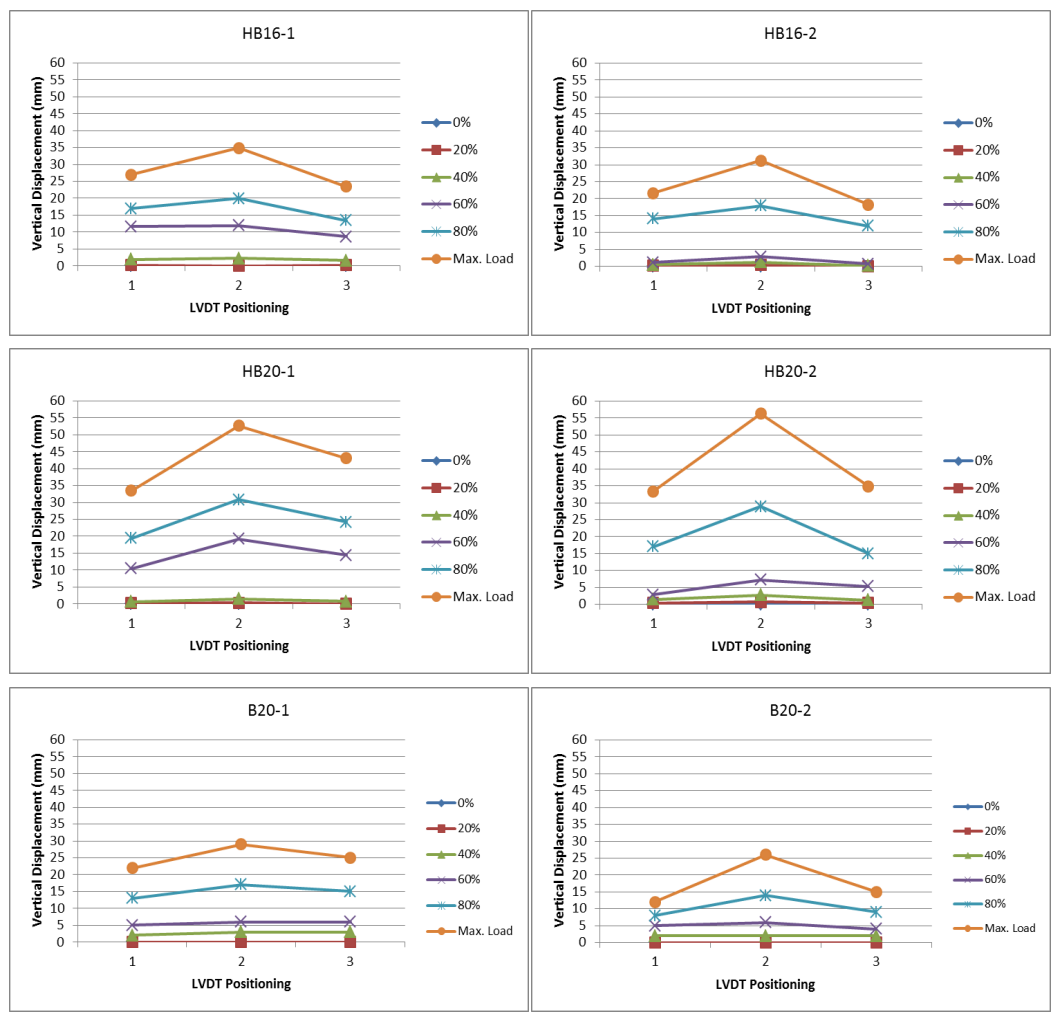

Figure 12: The Vertical Deformation of the T-Stub End Plate (source by author) 
All specimens showed similar behaviour and failure modes at the end of the test. All specimens' end-plates yielded at the flange plates and caused the end-plates to bend vertically upward before the bolts reached their yield point. Figure 12 shows the deformations of the T-stub end-plates before they reach their maximum loads during the test. Figure 13 shows the actual deformation of T-stub end plates for both types of bolts.

Other than the deformation of the end plates, the column faces of CFTST experienced punching failure and buckled outward due to the pull-out. In this experiment, the expanded sleeve of the Hollo-bolts did contribute largely to the performance because it gave more surface contact area between the bolts and concrete. At the end of the test, the bolts for all specimens were removed and are shown in Figure 13. HB16-1 and HB16-2 bolts show similar behaviour where all bolts bent at the contact area between the end plate and concrete core as in Figure 14(a). However, HB20-1, HB20-2, B20-1 and B20-2 did not deform and damage as much as the other bolts as shown in Figure 14(b).
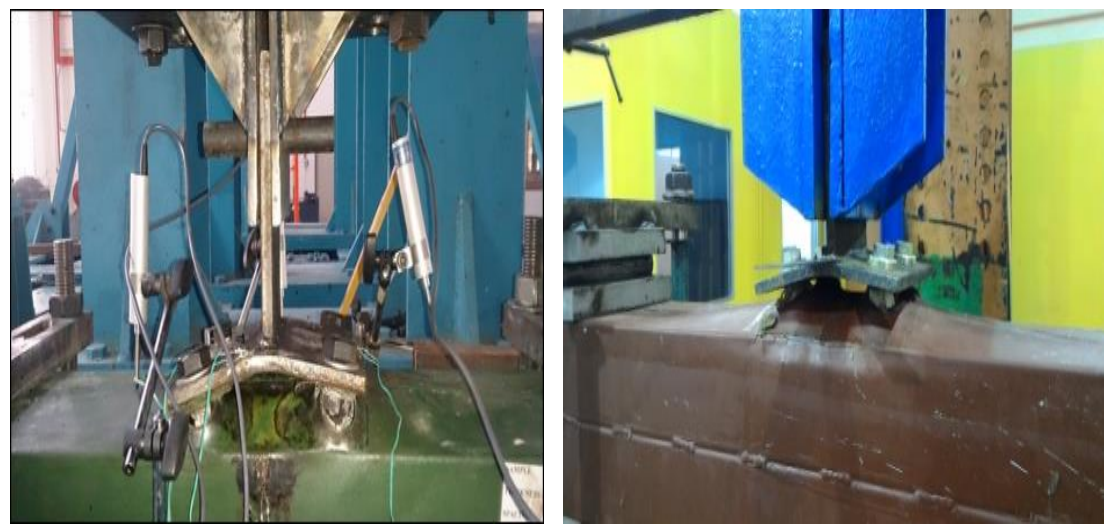

Figure 13: The Failure Modes of The Specimens (source by author) 


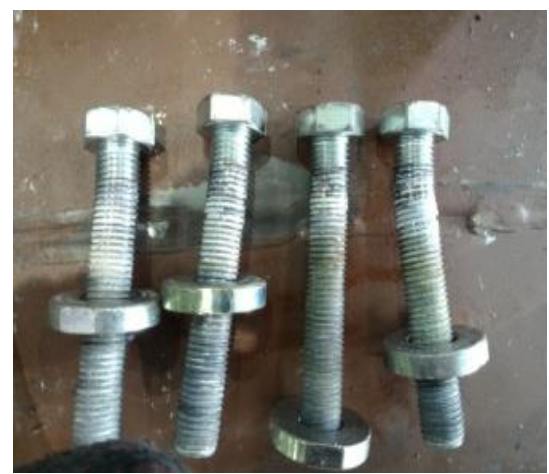

(a)

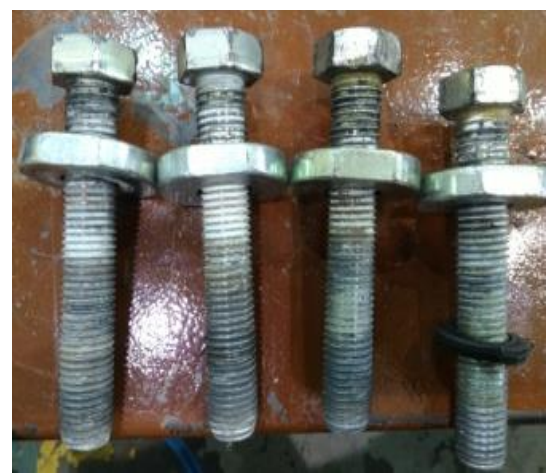

(b)

Figure 14: Deformation of Bolts After Test (source by author)

\section{CONCLUSION}

Currently, it can be concluded that the T-stub end plates with Lindapter Hollo-bolts showed better performance compare to the plates with normal bolts both, in terms of service and ultimate limit states, and deformation of the end plates. The lengths of bolts also give different outcome especially for Hollo-bolts because their sleeves were designed according to the length of the bolts. The longer bolt performed better in both limit states and the deformation of end plates. As for the design limit states, HB16-2, HB20-1 and HB20-2 perfomed equally good at service limit state but performed differently at ultimate limit state.

\section{RECOMMENDATION}

In this study, the test was restricted to the difference between having either normal bolts or Lindapter Hollo-bolts with constant end plate size for all specimens. There are other types of blind bolts and rivets such as Ajax blind bolt and flowdrill that can also be used as fasteners. By using these types of bolts instead with CFTST, it may give various outcomes that can be looked intofor a better understanding of thin walled structure connections. 


\section{ACKNOWLEDGEMENT}

Special thanks to Universiti Teknologi MARA(UiTM) for the subscription of SCOPUS, Science Direct and other electronic journals. Also the authors would like to give appreciation to VPN Engineering Sdn. Bhd. for supplying and fabricating the steel tubes. To all technicians at the Faculty of Civil Engineering, UiTM laboratories the authors indebted for their dedication and cooperation while carrying out the experimental work.

\section{REFERENCES}

[1] Industrialized Building System (IBS) Road Map (2003 - 2010), 2003, Lembaga Pembangunan Industri Pembinaan Malaysia (CIDB). Malaysia.

[2] M. Mursi, and B. Uy, 2004. Strength of slender concrete filled high strength steel box columns, Journal of Constructional Steel Research, Vol. 60(12), pp. 1825-1848. DOI: https://doi.org/10.1016/j. jcsr.2004.05.002.

[3] Z. Tao, L.H., Han, and Z.B., Wang, 2005. Experimental behaviour of stiffened concrete-filled thin-walled hollow steel structural (HSS) stub columns, Journal of Constructional Steel Research, Vol. 61(7), pp. 962-983. DOI: https://doi.org/10.1016/j.jcsr.2004.12.003.

[4] C. Petrus, A. H. Hanizah, I. Azmi and G. Parke, 2010. Experimental behaviour of concrete filled thin walled steel tubes with tab stiffeners, Journal of Constructional Steel Research, Vol. 66(7), pp. 915-922. DOI: https://doi.org/10.1016/j.jcsr.2010.02.006.

[5] C. Petrus, A. H. Hanizah, I. Azmi and D. N. Joe, 2011. Bond strength in concrete filled built -up steel tube columns with tab stiffeners, Canadian Journal of Civil Engineering, Vol. 38(6), pp. 627-637. DOI: https://doi.org/10.1139/111-030. 
[6] A. Elremaily and A. Azizinamini, 2002. Behavior and strength of circular concrete-filled tube columns, Journal of Constructional Steel Research. Vol. 58(12), pp. 1567-1591. DOI: https://doi.org/10.1016/ S0143-974X(02)00005-6.

[7] K. Abedi, A. Ferdousi and H. Afshin, 2008. A novel steel section for concrete-filled tubular columns, Thin-Walled Structure, Vol. 46(3), pp. 310-319. DOI: https://doi.org/10.1016/j.tws.2007.07.019.

[8] Y. M. Alostaz and S. P. Schneider, 1996. Analytical behavior of connections to concrete-filled steel tubes, Journal of Constructional Steel Research. Vol. 40(2), pp. 95-127. DOI: https://doi.org/10.1016/ S0143-974X(96)00047-8.

[9] A. P. Gardner and H. M. Goldsworthy, 2005. Experimental investigation of the stiffness of critical components in a moment-resisting composite connection, Journal of Constructional Steel Research, Vol. 61(5), pp. 709-726. DOI: https://doi.org/10.1016/j.jcsr.2004.11.004.

[10] J. F. Wang and S. P. Guo, 2012. Structural performance of blind bolted end plate joints to concrete-filled thin-walled steel tubular columns, Thin-Walled Structures, Vol. 60, pp. 54-68. DOI: https:// doi.org/10.1016/j.tws.2012.07.006.

[11] S. P. Schneider and Y. M. Alostaz, 1998. Experimental behavior of connections to concrete-filled steel tubes, Journal of Constructional Steel Research, Vol. 45(3), pp. 321-352. DOI: https://doi.org/10.1016/ S0143-974X(97)00071-0.

[12] E. N. Moreno, M. Banfi, D. Brown, M. Fewster, P. Gannon, C. Gibbons, B. Hairsine, A. Hughes, F., Kelly, A., Malik, D., Moore, C., Morris, D., Nethercot, A., Pillinger, S., Prestidge, A., Rathbone, R., Reed, C., Robinson, C., Robinson, G., Simmons, C., Colin Smart, B., Staley, M., Tiddy, and R., Weeden, 2011. Joints in Steel Construction: Simple Joints to Eurocode 3 (P358), England: The Steel Construction Institute (SCI). 
[13] Hollo-Bolt, 2013. The Original Expansion Bolt for Structural Steel, Lindapter, England.

[14] J., Lee, 2011. Blind Bolted Connections for Steel Hollow Section Columns in Low Rise Structures. Unpublished PhD's Thesis, Department of Civil and Environmental Engineering, University of Melbourne, Australia.

[15] International Institute of Welding (IIW), 1989. Design Recommendations for Hollow Section Joints - Predominantly Statically Loaded. 2nd ed. Helsinki, Finland. 

